\title{
The Effect of Classroom Climate on Academic Motivation Mediated by Academic Self-Efficacy in a Higher Education Institute in China
}

\author{
Qiumei Wang \\ University of Malaya, Kuala Lumpur, Malaysia \\ Youjiang Medical University for Nationalities, Baise, China \\ https://orcid.org/0000-0001-9698-059X \\ Kenny Cheah Soon Lee \\ University of Malaya, Kuala Lumpur, Malaysia \\ https://orcid.org/0000-0001-9881-582X \\ Kazi Enamul Hoque \\ University of Malaya, Kuala Lumpur, Malaysia \\ https://orcid.org/0000-0002-8152-9250
}

\begin{abstract}
Learning theories and empirical findings have widely recognized academic motivation as the driving force behind student academic performance. However, recent findings have indicated the need to pay attention to drive academic motivation among undergraduate students in China. Therefore, this present study examines the direct and indirect effects of classroom climate on student academic motivation in higher education. A total of 119 undergraduate students from a medical college in China was approached to respond to a survey questionnaire. The data analysis result shows that classroom climate significantly and positively affects student academic motivation and that the relationship is significantly mediated by academic self-efficacy. Particularly, the relationship established in this study additionally indicates that a planned and cohesive classroom climate can effectively improve student academic motivation. Indicatively, a planned and fair classroom climate effectually builds students' self-efficacy in their learning. This study highlights the indispensable and pivotal role that a positive classroom climate plays in motivating students to be more engaged and learn effectively. Also, the findings of this study provide guidance and references for stakeholders, school administrators, and lecturers in building and sustaining a positive and healthy classroom climate for better learning.
\end{abstract}

Keywords: Classroom Climate; Academic Motivation; Academic SelfEfficacy; Academic Performance 


\section{Introduction}

Learning theories like Self-determination Theory (Deci \& Ryan, 1985) and Selfworth Theory (Covington, 1992), as well as empirical researches, have clearly posited the crucial role that academic motivation plays in facilitating students' academic performance (Bailey \& Phillips, 2016; Cleary \& Kitsantas, 2017; Froiland \& Worrell, 2016; Ladd \& Sorensen, 2017). Effective learning process relies upon the triggering of academic motivation (Deci \& Ryan, 2000). Students who find interest, value, and enjoyment in the learning process, indicate more engagement and persistence in learning activities (Pelletier, Fortier, Vallerand \& Brière, 2001; Ratelle, Guay, Vallerand, Larose \& Senécal, 2007). Consequently, strongly motivated students exert more effort to complete tasks (Wolters, 2004), and display higher levels of academic achievement (Mega, Ronconi \& De Beni, 2014; Supervia \& Bordas, 2018). Evidently, the role of motivation in learning is heavily documented; however, the complexity and breadth of the notion of motivation requires an introspective lens using classroom climate and self-efficacy.

It is quite disturbing that researches have revealed a low level of academic motivation among undergraduate students (Gao \& Gao, 2015; Liu, 2013; Qiu, 2013), especially among science students in China (Gou, 2016; Zhao, 2015). In addition, only 45 percent of undergraduate students conveyed that they only focused on their studies in professional course classes. When it came to the selective course classes, the percentage declined to 18 percent (Wang \& Lin, 2018). This could be explained by the disconnection between the instructional goals employed in undergraduate courses and the classroom climate, which could have an influence on the academic and developmental motivation of learners (Lerdpornkulrat, Koul \& Poondej, 2018). Instructional strategies are not sufficient to drive motivation (Wang \& Lin, 2018) since motivation is individual-driven. Therefore, personal factors like self-efficacy could be a potential factor in improving students' motivation through the classroom environment.

Among various school factors, preceding studies tend to investigate the wellknown effects of teachers on students' academic motivation (Maulana, HelmsLorenz, Irnidayanti \& van de Grift, 2016; Saggaf, Nasriyah, Salam \& Wirawan, 2018); however, limited information is offered to explain the effects of classroom climate on student academic motivation and how the effect happens in higher education setting in China. In a systematic review of literature on the effects of classroom climate, Wang, Degol, Amemiya, Parr and Guo (2020) established the abundance of studies relating a positive learning environment with psychological well-being of students; however, it was noted that a great deal of these studies were centered on young learners as they cited the need to further examine this relationship in the higher education setting particularly in Asian countries. In response to this, an analysis of the relationship between classroom climate, academic self-efficacy, and students' motivation could establish the need to build and sustain a positive learning environment in higher education institutions in China.

Recent research conducted by Huang and Bai (2017) has found the positive influence of classroom climate on undergraduates' academic motivation and the 
mediating effect that self-efficacy exerts in their relationship. However, Huang and Bai (2017) did not take into account other factors regarding classroom climate except for classmate relation and teacher support, nor did they test the reliability and validity of the research instrument, which makes the findings questionable. Thus, this study presents a specific and validated illustration of the relationship among classroom climate, student academic motivation, and self-efficacy in the context of undergraduate medical students in China. On the strength of the above mentioned theoretical and empirical research approaches, three research questions are formulated for the present study:

1. How are perceived classroom climate and academic self-efficacy related to student academic motivation?

2. Which dimension of perceived classroom climate significantly predicts student academic motivation and academic self-efficacy?

3. Does academic self-efficacy have a mediating effect on the relationship between classroom climate and student academic motivation?

\section{Literature Review}

\section{Self-determination Theory}

This study takes Self-determination Theory (SDT) as an approach to understand student motivation in the classroom context. SDT presents a remarkable framework based on several motivation theories to understand the reciprocity of sociocultural conditions and individual personality (Deci \& Ryan, 2008). Besides the conceptualization of motivation from external to internal, SDT also emphasizes the concept of basic psychological needs. SDT theorists believe that three internal psychological needs in human nature need to be met through interaction with the environment: autonomy or the desire to establish inner coherence and to feel self-directed; competence or the needs to feel confident in one's interactions with the social environment through exercising and expressing one's abilities; relatedness or the desire to feel integral and connected with others (Deci \& Ryan, 1985; Ryan, Rigby \& Przybylski, 2006). Accordingly, the environment that satisfies or fulfils students' basic needs is predicted to support their self-motivation, engagement, and well-being. In organizations, the significance of motivation is determined by the extent it influences professional satisfaction, task performance, and holistic wellness (Deci, Olafsen \& Ryan, 2017). That is to say, the extent to which students' psychological needs are met by the perceived classroom climate is expected to be associated with their motivation to learn. 


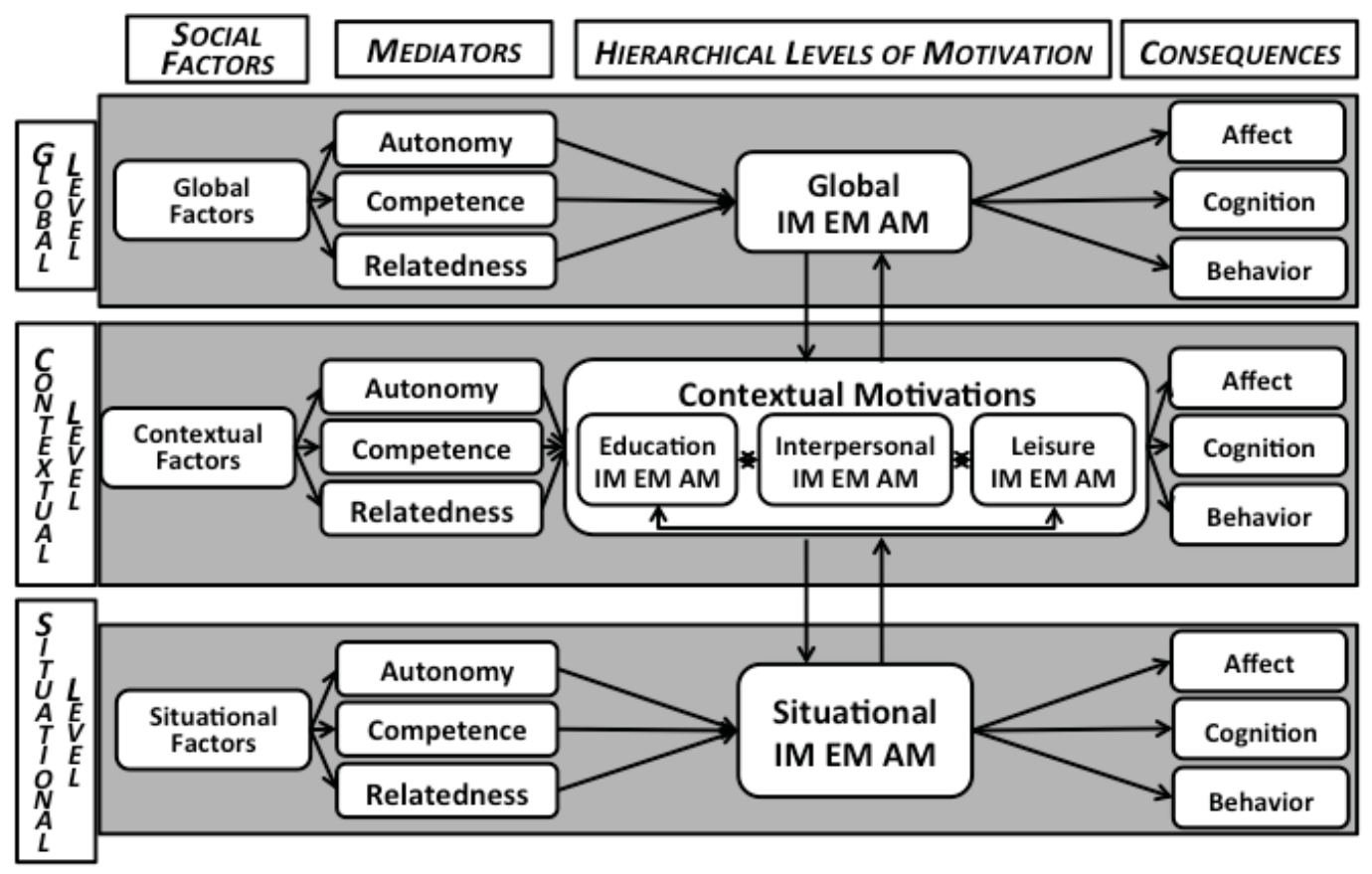

Figure 1: The Hierarchical Model for Motivation (source: Vallerand, 1997)

In order to differentiate short-term motivation from long-term motivation, SDT maps the Hierarchical Model for Motivation to categorize motivation into three levels: global, contextual, and situational (Guay, Mageau \& Vallerand, 2003; Vallerand, 1997; Vallerand, 2000) as shown in Figure 1. The global level is highly abstract since the motivational orientations of an individual are due to personal identity. The contextual level is less abstract as it describes the perceived relationship of an individual to other concrete materials or organizations like schools. The situational level, which is the focus of this study, is more specific compared to global and contextual levels because it depicts an individual's motivational response to a specific activity. In the educational setting, students' general feelings towards school and learning affect their approaches to the learning environment and tasks. Conversely, classroom learning activities can affect the students' approaches to learning in general (Stolk, Jacobs, Girard \& Pudvan, 2018).

\section{Academic Motivation}

Conceptualized in the context of SDT, academic motivation is the driving force that empowers students to learn or participate in the learning process (Ryan \& Deci, 2002). Academic motivation is usually divided into intrinsic motivation and extrinsic motivation (Ryan \& Deci, 2000). Intrinsic motivation has been conceptualized as the internal driving force of an individual to participate in a particular activity for his curiosity, interest, or fulfilment (Deci, Cascio \& Krusell, 1975). It is linked with other components like exploration, learning goals, and intrinsic intellectuality (Vallerand, 1992). In contrast, extrinsic motivation is an inducement for a person to participate in a particular activity so as to gain rewards or to avoid punishment (Dev, 1997). 
Academic motivation is recognized as one of the most effective driving forces of student learning (Tucker, Zayco \& Herman, 2002) as well as the only factor that guarantees students' academic achievement (Griffin, MacKewn, Moser \& VanVuren, 2012). Among the numerous factors contributing to students' performance and academic achievement, academic motivation is considered as one of the most significant elements (Tucker, Zayco \& Herman, 2002). Subsequently, it helps to enhance students' engagement (Pavlou, 2006), learning autonomy, and academic performance (Rana, Mahmood \& Reid, 2015) in teaching and learning processes. More importantly, intrinsic academic motivation also has a positive significance on the reduction of stress and depression of undergraduate students, which could bring about a positive classroom atmosphere free from interpersonal conflicts (Huang, Lv \& Wu, 2016).

\section{Classroom Climate}

Classroom climate is conceptualized as the intellectual, physical, emotional, and social environment in which students learn (Ambrose, Bridges, DiPietro, Lovett \& Norman, 2010). It includes the physical environment of the classroom, the interaction between teacher and students, and teacher's behavioral and academic expectations of the students (O'Brennan, Bradshaw \&Furlong, 2014). Wang et al. (2020) characterize a positive classroom setting as a safe, harmonious, and open environment, which could be influenced by the dynamics of the participants and the prevalent learning culture.

Empirical evidence suggests that a self-governed and healthy environment in the classroom positively contributed to students learning outcomes (Barksdale, 2017; Reyes, Brackett, Rivers, White \& Salovey, 2012), and academic motivation (Anderson, Hamilton \& Hattie, 2004). A classroom with a teacher's coaching and inspiration will lead to better coaching and encouragement among students, as well as motivation enhancement and prolonged student engagement (Seritanondh, 2013). Students in a teacher-supported and teacher-involved classroom indicate a higher level of motivation as students gain more enjoyment in the learning process and have more potential to achieve academic success; whereas, students in a classroom of teacher-control and peer-competition are more likely to face challenges like learning-weariness and anti-school feelings (Fry \& Coe, 1980). According to previous studies, a classroom climate of involvement, autonomy, and meaningfulness advances students' motivational goal orientation (Ciani, Middleton, Summer \& Sheldon, 2010; Lerdpornkulrat, Koul \& Poondej, 2018). A classroom with good interpersonal relationship promotes student intrinsic motivation (Levy-Tossman, Kaplan \& Assor, 2007; Nelson \& DeBacker, 2008). Conversely, a negative classroom climate with poor peer relationships deters the growth of students' autonomous motivation in mathematics (Reindl, Berner, Scheunpflug, Zeinz \& Dresel, 2015).

Additionally, in an agreeable and pleasant classroom climate, students feel safer, have more confidence in learning, and are not afraid of making mistakes (Morin, Marsh, Nagengast \& Scalas, 2014). A classroom climate of order significantly leads to the increase of reading motivation of efficacy, compliance, challenge, and aesthetics, and the whole process contributes to greater student academic 
achievement (Mucherah, Finch, Smith \& Ambrose-Stahl, 2014). Specifically, a teacher-centered classroom climate facilitates undergraduates' self-efficacy in mathematics learning (Peters, 2013).

\section{Academic Self-efficacy}

Academic self-efficacy is conceptualized as one's confidence in his or her ability to complete learning tasks or achieve educational goals (Bandura, 2007). It is found to be multi-faceted and could impact how individuals feel, think, and carry out instructive assignments (Sharma \& Nasa, 2014). Self-efficacy is developed on four bases of information, which are vicarious experiences, enactive mastery, physical and emotional states (Schunk \& Pajares, 2002). As such, academic selfefficacy could be pertinent in student educational performances as it comes along with corresponding behaviors and motivations that empower or debilitate compelling execution.

Scholars have posited that positive teaching and learning outcomes rely on affective and psychological factors like self-efficacy (Bandura, 1977). Students, who believe that they have adequate capacity to complete tasks, tend to take specific actions to achieve their learning goals, which will bring about positive academic outcomes and success (Bandura, 1977). Additionally, Veresova (2016) argued that student academic self-efficacy was resolutely associated with their academic motivation and contributed to their learning performance as well as academic achievement. Other empirical researches also confirmed the positive effects of student self-efficacy on their academic motivation (Chi \& Xin, 2006; Taheri-Kharameh, Sharififard, Asayesh, Sepahvandi \& Hoseini, 2018). These findings are reinforced by recent experimental research demonstrating that the training of self-efficacy-building strategies significantly contributes to the improvement of students' academic self-efficacy and motivation. In addition, the results also confirm the causal-effect relationship between academic self-efficacy and student motivation (Cave, Evans, Dewey \& Hartshorn, 2018).

\section{Method}

\section{Research Design}

A quantitative design and survey strategy were used to meet the research objectives. Data were drawn from 119 undergraduate students from a medical college located in Guangxi, China. Among the sample students, there were 25 males $(21 \%)$ and 91 females $(76.5 \%)$. The average age of the participants was 21 $(\mathrm{SD}=1.4)$. The online questionnaire was distributed to undergraduate medical students via QQ-email in different sessions. In PLS-SEM, the needed sample size could be calculated by means of power analyses according to the part of the model obtaining the largest number of predictors (Hair, Hult, Ringle \& Sarstedt, 2017). Hair, et al. (2017) further suggested researchers use Programs such as $G^{*}$ Power to do power analysis specific to model set-ups when utilizing PLS-SEM. G*power is a free online software used to do power analysis and sample size calculation. The analysis result of $G^{*}$ Power shows that the required sample size of this study is 92 (effect size $=.15$, alpha $=.05$, beta $=.80$, No. of predictor=5), indicating that 119 samples are adequate for data analysis and the sample size does not have an effect on the result. 


\section{Instruments}

The current study used a questionnaire adopted from several scales. These scales consisted of a total of 43 items with a numerical rating scale ranging from 1 (not agree at all) to 9 (highest agreement). As a first step, the instrument was sent to three experts to validate the content. Then, a panel of bilingual experts was invited to validate the translation via a double back translation technique (Zikmund, Babin, Carr \& Griffin, 2010).

\section{Classroom Climate}

Classroom climate was assessed with Classroom Climate Questionnaire (CCQ). The CCQ is a 26-item questionnaire developed by $\mathrm{Hu}$ (2010) to assess undergraduate students' perception of classroom climate in a college course. Classroom climate questionnaire includes five dimensions: a) cohesive, b) supportive, c) participative, d) planned, and e) fair. Cohesive dimension mainly reflects the extent to which students learn from each other, help each other, and support each other in the classroom. Supportive dimension focuses on the degree by which teachers are friendly, trustful, interested, and helpful to students in the classroom. Participative dimension reflects the degree of students' concentration, interest, participation, and enjoyment in classroom discussion and learning. Planned dimension refers to the extent by which students complete classroom activities, goals, and tasks. Fair dimension refers to the degree by which students are treated fairly by teachers. Reliabilities of the five dimensions are .904 (cohesive, $\mathrm{n}=6$ item), 921 (supportive, $\mathrm{n}=6$ item), 911 (participative, $\mathrm{n}=4$ item), .876 (planned, $\mathrm{n}=5$ item), and .929 (fair, $\mathrm{n}=5$ item). The results of confirmative factor analysis reveal that the indicator loading of each item is higher than .70, and AVE value of each dimension is in the range of $.67-.80$. In addition, the HTMT value of each dimension is smaller than .85 .

\section{Academic Self-efficacy}

Academic self-efficacy was measured by a sub-scale titled Self-Efficacy for Learning and Performance of Motivated Strategies for Learning Questionnaire (MSLQ) developed by Pintrich, Smith, Garcia, and McKeachie (1991). The subscale was utilized to measure the level of students' perceived ability and confidence in a course. MSLQ was designed on the basis of a general cognitive perspectives on learning motivation and strategies and a theoretical framework proposed by McKeachie, Pintrich, Lin, and Smith (1986). This instrument has been widely used for many years and has been tested as reliable and valid in contemporary researches (Basila, 2016; Bibi, 2017; Rush, 2013; Taylor, 2012, Vaculíková, 2016). The reliability test indicates a high reliability of this scale. The reliability of the self-efficacy is .936 ( $\mathrm{n}=8$ item). The result of confirmative factor analysis reveals that the indicator loading of each item is higher than .70, AVE value is .71, HTMT value is smaller than .85 .

\section{Student Academic Motivation}

Student academic motivation was measured by a sub-scale (i.e. goal orientation) of MSLQ. Goal orientation regards students' goals in a subject or course as a whole, i.e. academic motivation. Intrinsic goal orientation assessed students' selfperceived degrees to participate in learning tasks out of reasons like interest, curiosity, and challenge. Extrinsic goal orientation regards students' self- 
perceived degrees to participate in learning tasks out of reasons, for example grades, rewards, competing with others, or evaluation by others. Therefore, this study adopts intrinsic goal orientation to evaluate intrinsic motivation and extrinsic goal orientation to assess extrinsic motivation. Reliabilities of the two dimensions are .842 (intrinsic, $n=4$ item), and .866 (extrinsic, $n=4$ item). The result of confirmative factor analysis shows that the indicator loading of each item was higher than .70, and AVE value of each dimension is .68 and .72 respectively. Additionally, the HTMT value of each dimension is smaller than .85 .

\section{Results}

Table 1 summarizes the descriptive statistics of classroom climate (CC), selfefficacy (SE), academic motivation (AM), and the sub-constructs of classroom climate and academic motivation. The means of all constructs were higher than 6.34 , indicating that students showed a generally high level of perceived academic self-efficacy, academic motivation, and classroom climate.

Table 1: Mean, SD, Skewness and Kurtosis of Constructs

\begin{tabular}{lllll}
\hline Construct & Mean & SD & Skewness & Kurtosis \\
\hline Cohesive & 7.49 & .96 & -.54 & -.08 \\
Supportive & 6.42 & 1.29 & -.54 & .47 \\
Participative & 6.64 & 1.29 & -.61 & .74 \\
Planned & 7.31 & .96 & -.37 & -.18 \\
Fair & 7.23 & 1.18 & -.62 & .13 \\
Intrinsic & 7.34 & .99 & -.64 & .18 \\
Extrinsic & 7.52 & 1.08 & -.66 & .18 \\
SE & 7.04 & 1.09 & -.39 & -.21 \\
AM & 7.43 & .94 & -.67 & .17 \\
CC & 7.02 & .96 & -.34 & -.48 \\
\hline
\end{tabular}

With regard to the first research question, Pearson correlation was employed to analyze the relationship between perceived classroom climate, academic selfefficacy, and academic motivation using SPSS 24. Inter-correlations among the ten constructs are shown in Table 2. The result revealed strong correlation between classroom climate and academic self-efficacy $(\mathrm{r}=.75, \mathrm{p}<.001)$, classroom climate and academic motivation $(\mathrm{r}=.66, \mathrm{p}<.001)$, and students' self-efficacy and their academic motivation $(\mathrm{r}=.75, \mathrm{p}<.001)$. Unexpectedly, all the constructs were also strongly associated.

Table 2: Inter-correlations among Constructs

\begin{tabular}{|c|c|c|c|c|c|c|c|c|c|}
\hline Construct & 1 & 2 & 3 & 4 & 5 & 6 & 7 & 8 & 9 \\
\hline 1. CC & 1 & & & & & & & & \\
\hline 2. AM & $.66^{\star \star *}$ & 1 & & & & & & & \\
\hline 3.SE & $.75^{\star \star \star}$ & $.75^{* * *}$ & 1 & & & & & & \\
\hline 4.Cohesive & $.79^{* * *}$ & $.63^{*+*+x}$ & $.60^{* * *}$ & 1 & & & & & \\
\hline 5.Supportive & $.86^{\star \star *}$ & $.41^{* * * t}$ & $.53^{* \star *}$ & $.57^{\star \star \star}$ & 1 & & & & \\
\hline 6.Participative & $.89^{* \star \star}$ & $.48^{*+* *}$ & $.61^{* * \star}$ & $.62^{* * *}$ & $.81^{\star * *}$ & 1 & & & \\
\hline 7.Planned & $.83^{* * *}$ & $.72^{* * * *}$ & $.75^{* * *}$ & $.65^{* * *}$ & $.57^{\star * *}$ & $.63^{* * *}$ & 1 & & \\
\hline 8.Fair & $.83^{* * *}$ & $.60^{* * *}$ & $.69^{* * *}$ & $.59^{* \star *}$ & $.61^{* * *}$ & $.60^{* * *}$ & $.73^{* * *}$ & 1 & \\
\hline
\end{tabular}




\begin{tabular}{llllllllll} 
9.Intrinsic & $.64^{* * *}$ & $.90^{* * *}$ & $.74^{* * *}$ & $.61^{* * *}$ & $.40^{* * *}$ & $.47^{* * *}$ & $.70^{* * *}$ & $.59^{* * *}$ & 1 \\
10. Extrinsic & $.55^{* * *}$ & $.92^{* * *}$ & $.62^{* * *}$ & $.53^{* * *}$ & $.35^{* * *}$ & $.39^{* * *}$ & $.62^{* * *}$ & $.49^{* * *}$ & $.65^{* * *}$ \\
\hline
\end{tabular}

Note. ${ }^{* * *}$ Correlation is significant at the .001 level (2-tailed)

In order to examine which dimension of perceived classroom climate significantly predicts student academic motivation and academic self-efficacy, stepwise multiple regression technique was employed to explore the causal effect among the constructs. Table 3 illustrates the output of multiple regression analysis of the dimension of classroom climate on academic motivation and self-efficacy.

Table 3: Multiple Regression of Classroom Climate on Academic Motivation and Selfefficacy

\begin{tabular}{lllllll}
\hline $\begin{array}{l}\text { Dimension of } \\
\text { Classroom Climate }\end{array}$ & $\boldsymbol{b}$ & $\boldsymbol{\beta}$ & $\mathbf{t}$ & Sig. & $\mathbf{R}^{\mathbf{2}}$ & \% \\
\hline Planned-> AM & .532 & .546 & 6.526 & .000 & .518 & 51.8 \\
Cohesive-> AM & .265 & .271 & 3.244 & .002 & .557 & 3.9 \\
Planned-> SE & .602 & .531 & 6.044 & .000 & .567 & 56.7 \\
Fair-> SE & .281 & .304 & 3.462 & .001 & .603 & 3.8 \\
\hline
\end{tabular}

The above result specified that among the five dimensions of classroom climate, two dimensions significantly correlate and contribute $(55.7 \%)$ to student academic motivation. The dominant planned dimension $(\beta=.546, p=.000)$ was found to contribute $51.8 \%$ of the variance to student academic motivation, and the cohesive dimension $(\beta=.271, p=.002)$ contribute $3.9 \%$ of the variance to academic motivation. Accordingly, when the planned dimension and cohesive dimension of the classroom climate increase by one unit of standard deviation, student academic motivation will increase by .546 and .271 unit of standard deviation, respectively. Hence, the planned dimension and cohesive dimension have a strong and modest effect on student academic motivation (Muijs, 2011), respectively.

In regard to the significant predictors of classroom climate to student academic self-efficacy, the dimension of planned $(\beta=.531, p=.000)$ and fair $(\beta=.304, p=.001)$ were concluded in the prediction model. The planned dimension was found to contribute $56.7 \%$ of the variance to academic self-efficacy $\left(\mathrm{R}^{2}=.567\right)$, and the combination of planned and fair dimensions accounted for $60.3 \%$ of the student self-efficacy $\left(R^{2}=.603\right)$. Based on the interpretation showed in Table 4 , the two models demonstrated a large effect size on academic self-efficacy as a whole. Additionally, the dimension of planned and fair had a strong and modest effect on self-efficacy, respectively.

Subsequently, software SmartPLS 3 was applied to examine the indirect influence that academic self-efficacy exerted on the relationship between classroom climate and student academic motivation. Table 4 covers the relationship between variables in the model, and Figure 2 presents a structural illustration of the relationships. In Figure 2, the inner model depicts the path coefficients $(\beta)$ and Tvalues, and the outer model shows the T-values. 
Table 4: Summary of the Direct and Indirect Effect in the Model

\begin{tabular}{llll}
\hline Path & $\boldsymbol{\beta}$ & $\mathbf{t}$ & Sig. \\
\hline CC $>$ AM & .242 & 2.454 & .014 \\
CC -> SE & .762 & 16.409 & .000 \\
SE -> AM & .576 & 6.356 & .000 \\
CC $>$ SE -> AM & & 5.688 & .000 \\
\hline
\end{tabular}

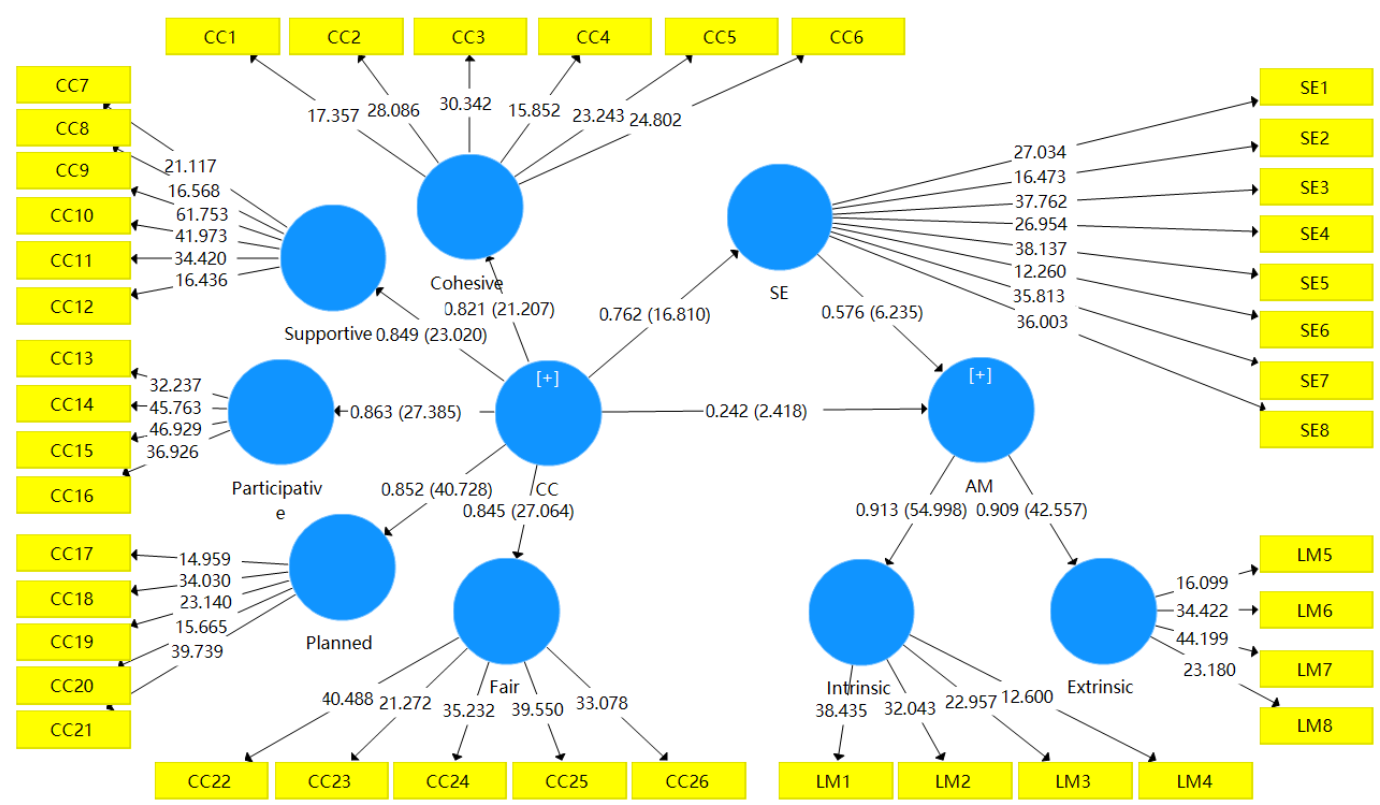

Figure 2: The Structural Model Assessment

According to the output shown in Figure 2 and table 4, the direct effect of classroom climate on student academic motivation is estimated at $\beta=.242$, and the indirect effect which is the multiplication of both indirect paths $(.762 \times .576)$ equals to .439 , leaving the standardized total effect (indirect + direct) at .681 (Hair et al, 2010). The direct path of classroom climate and academic motivation is supported; meanwhile, the two indirect paths (classroom climate -- academic self-efficacy -academic motivation) are also confirmed (see Table 4). The result reveals that academic self-efficacy partially mediates the relationship between classroom climate and student academic motivation since both direct and indirect effects are established.

\section{Discussion}

Results obtained from data analysis have a number of implications; however, they should be interpreted with SDT and previous related findings.

First, the classroom climate significantly and positively affects student academic motivation. The findings of this study affirm the research results of Huang and Bai (2017) and Lerdpornkulrat (2018), which indicated that a healthy and positive classroom climate was pivotal for the improvement of student academic motivation. Specifically, a cohesive classroom climate, in which students learn and support each other, significantly improves academic motivation. This is 
echoed by the findings of Anderson et al. (2004) noting that when secondary students felt a higher level of friendship in a classroom, they were more motivated to learn. More importantly, a planned classroom, in which students complete classroom tasks in high quality, greatly contributes to the improvement of student academic motivation $\left(\mathrm{R}^{2}=51.8 \%\right)$.

Nevertheless, this study also found that a supportive classroom climate was closely correlated with $(p<.001)$ but insignificantly influences student academic motivation. This is aligned with the previous findings (Fry \& Coe, 1980) that teacher support was indispensable for the enhancement of student academic motivation; however, this is inconsistent with the findings of Huang and Bai (2017) stating that teacher support significantly and positively influenced student academic motivation. A probable reason for this inconsistency could have been the participant characteristics. As adult learners, undergraduates are less affected by teachers compared with primary and secondary students. According to the latest research, medical students indicated a higher level of autonomy in learning (Su, Ye, Li, Wei, Du \& Lu, 2014). They have heavy learning tasks and devote a long time in learning so as to meet their higher academic requirements, making them live in a comparatively strong and competitive learning atmosphere. This atmosphere consequences further facilitates the development of their autonomy learning.

Second, the influence of classroom climate on student academic motivation is mediated by academic self-efficacy. The result is consistent with SDT and the findings reported in the research conducted in mainland China context (Huang \& Bai, 2017). Students, who believe that their psychological needs are met in the social environment or who study in a positive and healthy classroom climate, indicate a higher level of confidence in their ability and academic motivation.

Third, a planned and fair classroom contributed to the improvement of selfefficacy. This is echoed by the research findings of Mucherah et al. (2014), which shows that a well-planned classroom climate helps to increase students' reading motivation. When the students complete classroom learning tasks and are treated equally, it helps them to build their self-confidence to achieve their learning goals and then improves their motivation to pursue personal development.

Fourth, the descriptive result recommends that the respondents of this study are highly motivated to learn. This is contradictory to the findings of Gao \& Gao (2015), Liu (2013), and Qiu (2013) which indicate the insufficiency of academic motivation among college students. A conceivable explanation for this might be the better academic background of medical students compared with other disciplined students. In China, high school students need to get a higher score in the national college entrance examination so as to get the chance to be medical students.

Finally, the planned dimension of classroom climate has a very robust impact on student motivation $(\beta=.546)$ and self-efficacy $(\beta=.531)$, indicating that among the three psychological needs, competence is the most important for undergraduate 
medical students in China. Overall, this finding is supported by the assumptions of SDT.

\section{Conclusion}

After analyzing the data collected from 119 medical students from a higher education institute, the results concluded the significant influence that classroom climate exerted on student academic motivation and the mediating effect of academic self-efficacy in the relationship. This study also indicated that among the five dimensions of classroom climate, a planned and fair classroom climate significantly improved student self-efficacy and a cohesive and planned classroom climate helps to motivate students to learn. This stresses the essence of a healthy and well-organized classroom climate in student learning. For policymakers and stakeholders, more related educational policies regarding classroom climate should be made, and they can also set classroom climate evaluation as a criterion to assess education practitioners. Standards regarding the management of positive classroom climates are heavily valued in America (Schonert-Reichl et al, 2017); whereas, related standards and policies in China cannot be found in the present literature. For school administrators, they need to safeguard teachers' actions within the classroom, which are consistent with research-based factors advised by this study and previous literature to promote student academic motivation and performance. Also, school administrators can launch programs that can effectively facilitate the classroom climate to improve student academic motivation. For lecturers, they can obtain the message that the promotion of a positive classroom climate is highly crucial and beneficial for students' academic performance. They can also build a classroom environment with a harmonious student relationship, treat the students in an equivalent way, and offer them more prospects to complete learning tasks. Despite the highlighted significant contributions of this study, further research could give a generalizable perspective by covering a larger sample size and population from different colleges and universities. In addition, exploratory studies could further explain the ways classroom environment are designed to further motivate students and improve their self-efficacy. Nevertheless, the findings of this study accentuate the notion that more meaning should be embedded in the design of learning tasks to meet students' needs of competence and to build their confidence and motivation.

\section{References}

Ambrose, S. A., Bridges, M. W., DiPietro, M., Lovett, M. C., \& Norman, M. K. (2010). How learning works: Seven research-based principles for smart teaching. CA: John Wiley \& Sons.

Anderson, A., Hamilton, R. J., \& Hattie, J. (2004). Classroom climate and motivated behaviour in secondary schools. Learning Environments Research, 7(3), 211-225. doi:10.1007/s10984-004-3292-9

Bailey, T. H., \& Phillips, L. J. (2016). The influence of motivation and adaptation on students' subjective well-being, meaning in life and academic performance. Higher education research $\mathcal{E}$ development, 35(2), 201-216. doi:10.1080/07294360.2015.1087474 
Bandura, A. (2007). Much ado over a faulty conception of perceived self-efficacy grounded in faulty experimentation. Journal of Social and Clinical Psychology, 26, 641-658. doi:10.1521/jscp.2007.26.6.641

Barksdale, C. J. (2017). Examining the Relationship Between Classroom Climate and Student Achievement of Middle School Students (Ed.D. Thesis). University of Houston-Clear Lake, Ann Arbor.

Basila, C. L. (2016). Academic performance in college online courses: The role of self-regulated learning, motivation and academic self-efficacy (Ph.D. Thesis). State University of New York at Albany, Ann Arbor.

Bibi, A. (2017). Factors affecting Differential Equation Problem Solving Ability of Pre-university Level Students In a Selected Province in Pakistan (Unpublished Doctroral Dissertation). Kuala Lumpur, Malaysia: University of Malaya.

Cave, P. N., Evans, N. W., Dewey, D. P., \& Hartshorn, K. J. (2018). Motivational partnerships: increasing ESL student self-efficacy. Elt Journal, 72(1), 83-96. doi:10.1093/elt/ccx027

Chi, L. P., \& Xin, Z. Q. (2004). The Measurement of Learning Motivation and its Relationship with Self-Efficacy among College Students. Psychological Development and Education, 21(2), 64-70.

Ciani, K. D., Middleton, M. J., Summers, J. J., \& Sheldon, K. M. (2010). Buffering against performance classroom goal structures: The importance of autonomy support and classroom community. Contemporary educational psychology, 35(1), 88-99. doi:10.1016/j.cedpsych.2009.11.001

Cleary, T. J., \& Kitsantas, A. (2017). Motivation and self-regulated learning influences on middle school mathematics achievement. School Psychology Review, 46(1), 88-107. doi:10.17105/spr46-1.88-107

Covington, M. V. (1992). Making the grade: A self-worth perspective on motivation and school reform. Cambridge University Press.

Deci, E. L., Cascio, W. F., \& Krusell, J. (1975). Cognitive evaluation theory and some comments on the Calder and Staw critique. Journal of personality and social psychology, 31(1), 81-85. doi:10.1037/h0076168

Deci, E. L., \& Ryan, R. M. (1985). The general causality orientations scale: Selfdetermination in personality. Journal of research in personality, 19(2), 109-134. doi:10.1016/0092-6566(85)90023-6

Deci, E. L., \& Ryan, R. M. (2000). The "what" and "why" of goal pursuits: Human needs and the self-determination of behavior. Psychological Inquiry, 11(4), 227-268. doi:10.1207/s15327965pli1104_01

Deci, E. L., Olafsen, A. H., \& Ryan, R. M. (2017). Self-determination theory in work organizations: The state of a science. Annual Review of Organizational Psychology and Organizational Behavior, 4, 19-43.

Dev, P. C. (1997). Intrinsic motivation and academic achievement: What does their relationship imply for the classroom teacher?. Remedial and special education, 18(1), 12-19. doi:10.1177/074193259701800104

Froiland, J. M., \& Worrell, F. C. (2016). Intrinsic motivation, learning goals, engagement, and achievement in a diverse high school. Psychology in the Schools, 53(3), 321-336. doi:10.1002/pits.21901

Fry, P., \& Coe, K. (1980). Interaction among dimensions of academic motivation and classroom social climate: A study of the perceptions of junior high and high school pupils. British Journal of Educational Psychology, 50(1), 33-42. doi:10.1111/j.20448279.1980.tb00795.x 
Gao, X. L., \& Gao, L., (2015) The characteristics and grade differences in learning motivation, learning strategies, learning investment among undergraduate students. China Journal of Health Psychology, 23 (2), 274-277.

Gold, A. H., Malhotra, A., \& Segars, A. H. (2001). Knowledge management: an organizational capabilities perspective. Journal of Management Information Systems, 18(1), 185-214. doi:10.1080/07421222.2001.11045669

Gou, Y. K. (2016). The Relationship between College Students' Social Support, Achievement Motivation, and Mobile Phone Dependence (Master's thesis). Shandong Normal University, Jinan.

Griffin, R., MacKewn, A., Moser, E., \& VanVuren, K. (2012). Do learning and study skills affect academic performance? An empirical investigation. Contemporary Issues in Education Research, 5(2), 1-7. doi:10.19030/cier.v5i2.6928

Guay, F., Mageau, G. A., \& Vallerand, R. J. (2003). On the Hierarchical Structure of SelfDetermined Motivation: A Test of Top-Down, Bottom-Up, Reciprocal, and Horizontal Effects. Personality and Social Psychology Bulletin, 29(8), 992-1004. doi:10.1177/0146167203253297

Hair, J. F., Black, W. C., Babin, B. J., Anderson, R. E., \& Tatham, R. L. (2010). Multivariate Data Analysis: Pearson education. Upper Saddle River, New Jersey: Pearson Prentice Hall.

Hair Jr, J. F., Sarstedt, M., Hopkins, L., \& G. Kuppelwieser, V. (2014). Partial least squares structural equation modeling (PLS-SEM) An emerging tool in business research. European Business Review, 26(2), 106-121. doi:10.1108/ebr-10-2013-0128

Hair Jr, J. F., Sarstedt, M., Ringle, C. M., \& Gudergan, S. P. (2017). Advanced issues in partial least squares structural equation modeling. Sage Publications.

Hair Jr, J. F., Hult, G. T. M., Ringle, C., \& Sarstedt, M. (2017). A primer on partial least squares structural equation modeling (PLS-SEM) (Second ed.). Los Angeles: Sage publications.

Henseler, J., Ringle, C. M., \& Sarstedt, M. (2015). A new criterion for assessing discriminant validity in variance-based structural equation modeling. Journal of the Academy of Marketing Science, 43(1), 115-135. doi:10.1007/s11747-014-0403-8

Hu, Z. X. (2010). Research on the Assessment Model of Class Climate in higher Education Institutes. Heilongjiang Researches on Higher Education. 28(2), 46-49.

Huang, C., \& Bai, Q.-h. (2017). The Relationship Between Classroom Climate, Self-Efficacy, and Learning Motivation. DEStech Transactions on Social Science, Education and Human Science, 308-312. doi:10.12783/dtssehs/ermm2017/14731

Huang, Y., Lv, W., \& Wu, J. (2016). Relationship between intrinsic motivation and undergraduate students' depression and stress: the moderating effect of interpersonal conflict. Psychological reports, 119(2), 527-538.

Khalaila, R. (2015). The relationship between academic self-concept, intrinsic motivation, test anxiety, and academic achievement among nursing students: Mediating and moderating effects. Nurse Education Today, 35(3), 432-438. doi:10.1016/j.nedt.2014.11.001

Kline, R. B. (2011). Principles and practice of structural equation modeling. New York: Guilford Press.

Ladd, H. F., \& Sorensen, L. C. (2017). Returns to teacher experience: Student achievement and motivation in middle school. Education Finance and Policy, 12(2), 241-279. doi:10.1162/edfp_a_00194

Lerdpornkulrat, T., Koul, R., \& Poondej, C. (2018). Relationship between perceptions of classroom climate and institutional goal structures and student motivation, engagement and intention to persist in college. Journal of Further and Higher Education, 42(1), 102-115. doi:10.1080/0309877x.2016.1206855 
Levy-Tossman, I., Kaplan, A., \& Assor, A. (2007). Academic goal orientations, multiple goal profiles, and friendship intimacy among early adolescents. Contemporary Educational Psychology, 32(2), 231-252. doi:10.1016/j.cedpsych.2006.06.001

Liu, W. (2013). The current situation of learning motivation and learning strategies among independent college students (Master's thesis). Liaoning Normal University, Liaoning.

Maulana, R., Helms-Lorenz, M., Irnidayanti, Y., \& van de Grift, W. (2016). Autonomous motivation in the Indonesian classroom: Relationship with teacher support through the lens of self-determination theory. The Asia-Pacific Education Researcher, 25(3), 441-451. doi:10.1007/s40299-016-0282-5

Mega, C., Ronconi, L., \& De Beni, R. (2014). What makes a good student? How emotions, self-regulated learning, and motivation contribute to academic achievement. Journal of educational psychology, 106(1), 121. doi:10.1037/a0033546

McKeachie, W. J., Pintrich, P. R., Lin, Y. G., \& Smith, D. (1986). Teaching and learning in the college classroom: A review of the research literature. Ann Arbor, MI: National Center for Research to Improve Postsecondary Teaching and Learning, The University of Michigan.

Morin, A. J. S., Marsh, H. W., Nagengast, B., \& Scalas, L. F. (2014). Doubly Latent Multilevel Analyses of Classroom Climate: An Illustration. Journal of Experimental Education, 82(2), 143-167. doi:10.1080/00220973.2013.769412

Mucherah, W., Finch, H., Smith, V., \& Ambrose-Stahl, D. (2014). Exploring the relationship between classroom climate, reading motivation, and achievement: A look into 7th grade classrooms. International Journal of Learning, Teaching and Educational Research, 8(1), 93-110.

Muijs, D. (2011). Doing Quantitative Research in Education with SPSS (Second ed.). Thousand Oaks, CA: SAGE Publications Inc.

Nelson, R. M., \& DeBacker, T. K. (2008). Achievement motivation in adolescents: The role of peer climate and best friends. The journal of experimental education, 76(2), 170 189. doi:10.3200/jexe.76.2.170-190

O'Brennan, L. M., Bradshaw, C. P., \& Furlong, M. J. (2014). Influence of Classroom and School Climate on Teacher Perceptions of Student Problem Behavior. School Mental Health, 6(2), 125-136. doi:10.1007/s12310-014-9118-8

Pavlou, V. (2006). Pre-adolescents' perceptions of competence, motivation and engagement in art activities. International Journal of Art E Design Education, 25(2), 194-204. doi:10.1111/j.1476-8070.2006.00484.x

Pelletier, L. G., Fortier, M. S., Vallerand, R. J., \& Brière, N. M. (2001). Associations Among Perceived Autonomy Support, Forms of Self-Regulation, and Persistence: A Prospective Study. Motivation and Emotion, 25(4), 279-306.

Pintrich, P. R., Smith, D. A., García, T., \& McKeachie, W. J. (1991). A manual for the use of the motivational strategies for learning questionnaire (MSLQ). Ann Arbor, MI: University of Michigan, National Center for Research to Improve Postsecondary Teaching and Learning.

Qiu. K. R. (2013). An Empirical Study of College Students' Learning Motivation - - Based on the Survey of 6 Universities (Master's thesis). Shantou University, Shantou.

Rana, R. A., Mahmood, N., \& Reid, N. (2015). Motivation and science performance: influence on student learning in science. Science Institute (Lahore), 27(2), 1445-1452.

Ratelle, C. F., Guay, F., Vallerand, R. J., Larose, S., \& Senécal, C. (2007). Autonomous, controlled, and amotivated types of academic motivation: A person-oriented analysis. Journal of Educational Psychology, 99(4), 734-746. doi:10.1037/00220663.99.4.734 
Reindl, M., Berner, V. D., Scheunpflug, A., Zeinz, H., \& Dresel, M. (2015). Effect of negative peer climate on the development of autonomous motivation in mathematics. Learning and Individual Differences, 38, 68-75. doi:10.1016/j.lindif.2015.01.017

Ryan, R. M., \& Deci, E. L. (2000). Intrinsic and extrinsic motivations: Classic definitions and new directions. Contemporary educational psychology, 25(1), 54-67. doi:10.1006/ceps.1999.1020

Ryan, R. M., Rigby, C. S., \& Przybylski, A. (2006). The motivational pull of video games: A self-determination theory approach. Motivation and emotion, 30(4), 344-360. doi:10.1007/s11031-006-9051-8

Rush, K. (2013). A Quantitative Evaluation of Gender, Nationality, and Generational/Age Influence on Academic Motivation. (Ph.D.). Northcentral University, Ann Arbor.

Saggaf, M. S., Nasriyah, N., Salam, R., \& Wirawan, H. (2018). The Influence of Teacher's Pedagogic Competence on Learning Motivation of Student of Office Administration Expertise Package. Paper presented at the 8th International Conference of Asian Association of Indigenous and Cultural Psychology (ICAAIP 2017). doi: 10.2991/icaaip-17.2018.24

Sarstedt, M., Ringle, C. M., Smith, D., Reams, R., \& Hair Jr, J. F. (2014). Partial least squares structural equation modeling (PLS-SEM): A useful tool for family business researchers. Journal of Family Business Strategy, 5(1), 105-115. doi:10.1016/j.jfbs.2014.01.002

Schonert-Reichl, K. A., Kitil, M. J., \& Hanson-Peterson, J. (2017). To reach the students, teach the teachers: A national scan of teacher preparation and social and emotional learning. A report prepared for the CASEL. Collaborative for Academic, Social, and Emotional Learning (CASEL). Vancouver, B.C.: University of British Columbia.

Schunk, D. H., \& Pajares, F. (2002). The development of academic self-efficacy. In Development of achievement motivation (pp. 15-31). Academic Press.

Seritanondh, S. (2013). Teacher leadership styles and student psychological characteristics affecting the study methods of foundation English courses in higher education: A case study of education and humanity/liberal arts students in Thailand. The Journal of Behavioral Science, 8(1), 17-36.

Sharma, H. L., \& Nasa, G. (2014). Academic self-efficacy: A reliable predictor of educational performances. British Journal of Education, 2(3), 57-64.

Stolk, J. D., Jacobs, J., Girard, C., \& Pudvan, L. (2018). Learners' Needs Satisfaction, Classroom Climate, and Situational Motivations: Evaluating Self-Determination Theory in an Engineering Context. 2018 IEEE Frontiers in Education Conference (FIE), 1-5. doi:10.1109/fie.2018.8658880

Su. Z. P., Ye, P., Li, J. P., Wei, T. Du, Z. M., \& Lu, Z. J. (2014). Analysis on the Differences of Autonomous Learning Ability of Medical Undergraduates. CHINA MEDICAL EDUCATION TECHNOLOGY, 28(4): 444-451.

Supervia, P. U., \& Bordas, C. S. (2018). School Motivation, Emotional Intelligence and Academic Performance in Students of Secondary Education. Actualidades En Psicologia, 32(125), 95-112.

Taheri-Kharameh, Z., Sharififard, F., Asayesh, H., Sepahvandi, M., \& Hoseini, M. H. (2018). Relationship between Academic Self-efficacy and Motivation among Medical Science Students. Journal of Clinical and Diagnostic Research, 12(7), 7-10. doi: 10.7860/JCDR/2018/29482.11770

Taylor, R. (2012). Review of the motivated strategies for learning questionnaire (MSLQ) using reliability generalization techniques to assess scale reliability (Doctoral dissertation). Auburn University, Auburn. 
Tucker, C. M., Zayco, R. A., \& Herman, K. C. (2002). Teacher and child variables as predictors of academic engagement among low-income African American children. Psychology in the Schools, 39(4), 477-488. doi:10.1002/pits.10038

Vaculíková, J. (2016). The Third Round of the Czech Validation of the Motivated Strategies for Learning Questionnaire (MSLQ). International Education Studies, 9(7), 35-46.

Vallerand, R. J. (1997). Toward a hierarchical model of intrinsic and extrinsic motivation. In Advances in experimental social psychology (Vol. 29, pp. 271-360). Academic Press.

Vallerand, R. J. (2000). Deci and Ryan's self-determination theory: A view from the hierarchical model of intrinsic and extrinsic motivation. Psychological Inquiry, 11(4), 312-318. URL: http://www.jstor.org/stable/1449629.

Verešová, M., \& Foglová, L. (2016). Academic self-Efficacy, heteronomous and autonomous evaluation of academic achievement of adolescents. Paper presented at the 7th International Conference on Education and Educational Psychology (ICEEPSY 2016). URL: http://dx.doi.org/10.15405/epsbs.2016.11.91

Wang, M. T., Degol, J. L., Amemiya, J., Parr, A., \& Guo, J. (2020). Classroom climate and children's academic and psychological wellbeing: A systematic review and metaanalysis. Developmental Review, 57, 100912.

Wang, Q., \& Lin, J. (2018). An Empirical Analysis of the Status Quo of Learning Situation and Motivation among College Students--Taking college Students in Shanxi University Communities as an Example. University Education, 9(12):143-146.

Zikmund, W. G., Babin, B. J., Carr, J. C., \& Griffin, M. (2010). Business Research Methods (8th ed.). Mason, OH: South-Western Ceng.

Zhao, H. J. (2015) The relationship between learning burnout and learning motivation: the mediating role of attribution (Master's thesis). Southwest University, Chongqing. 


\section{Appendix 1}

Dear students,

\section{Questionnaire for students}

This survey is conducted to better understand the relationship between classroom climate, student academic self-efficacy and learning motivation so as to provide reference for the improvement of teaching and learning quality.

The questionnaire only needs to be answered according to your actual situation, there is no right or wrong answer. This survey does not require you to provide your names, and your answers are kept confidential. We sincerely hope to get your cooperation and support. Thank you.

Part I: Demographic Information

Please tick or fill in your relevant information in the description below

Gender: $\quad$ A. male $\quad$ B. female
School Year: A. 1
B. 2
C. 3
D. 4

Age:

Part II:

Please circle one of the options that you think is most suitable in the following items in accordance with your actual situation. For example:

not agree at all

\begin{tabular}{|l|l|l|l|l|l|l|l|l|}
\hline 1 & 2 & 3 & 4 & 5 & 6 & 7 & 8 & 9 \\
\hline
\end{tabular}

highest agreement

classroom climate

\begin{tabular}{|c|c|c|c|c|c|c|c|c|c|c|}
\hline \multicolumn{2}{|r|}{ Item } & \multicolumn{9}{|c|}{$\begin{array}{l}1=\text { not agree at all } \\
9=\text { highest agreement }\end{array}$} \\
\hline 1 & I am very friendly to my classmates. & 1 & 2 & 3 & 4 & 5 & 6 & 7 & 8 & 9 \\
\hline 2 & $\begin{array}{l}\text { Many of the students in this course are } \\
\text { my friend }\end{array}$ & 1 & 2 & 3 & 4 & 5 & 6 & 7 & 8 & 9 \\
\hline 3 & $\begin{array}{l}\text { I am very happy to work with my } \\
\text { classmates on this course. }\end{array}$ & 1 & 2 & 3 & 4 & 5 & 6 & 7 & 8 & 9 \\
\hline 4 & $\begin{array}{l}\text { I will help my classmates in this course } \\
\text { if they have trouble. }\end{array}$ & 1 & 2 & 3 & 4 & 5 & 6 & 7 & 8 & 9 \\
\hline 5 & The classmates in this course like me. & 1 & 2 & 3 & 4 & 5 & 6 & 7 & 8 & 9 \\
\hline 6 & $\begin{array}{l}\text { In this course, I got help from other } \\
\text { students. }\end{array}$ & 1 & 2 & 3 & 4 & 5 & 6 & 7 & 8 & 9 \\
\hline 7 & The lecturer is concerned about me. & 1 & 2 & 3 & 4 & 5 & 6 & 7 & 8 & 9 \\
\hline 8 & $\begin{array}{l}\text { The lecturer took the trouble to help } \\
\text { me. }\end{array}$ & 1 & 2 & 3 & 4 & 5 & 6 & 7 & 8 & 9 \\
\hline 9 & The lecturer cares about my feeling. & 1 & 2 & 3 & 4 & 5 & 6 & 7 & 8 & 9 \\
\hline 10 & The lecturer is happy to talk to me. & 1 & 2 & 3 & 4 & 5 & 6 & 7 & 8 & 9 \\
\hline 11 & $\begin{array}{l}\text { The lecturer is interested in the learning } \\
\text { problems I have encountered. }\end{array}$ & 1 & 2 & 3 & 4 & 5 & 6 & 7 & 8 & 9 \\
\hline 12 & $\begin{array}{l}\text { The lecturer walked around the } \\
\text { classroom and talked to us. }\end{array}$ & 1 & 2 & 3 & 4 & 5 & 6 & 7 & 8 & 9 \\
\hline
\end{tabular}




\begin{tabular}{|c|c|c|c|c|c|c|c|c|c|c|}
\hline 13 & $\begin{array}{l}\text { I put forward my own point of view in } \\
\text { the discussion. }\end{array}$ & 1 & 2 & 3 & 4 & 5 & 6 & 7 & 8 & 9 \\
\hline 14 & $\begin{array}{l}\text { My insights and opinions are used in } \\
\text { class discussion. }\end{array}$ & 1 & 2 & 3 & 4 & 5 & 6 & 7 & 8 & 9 \\
\hline 15 & $\begin{array}{l}\text { Classmates and I discuss ways to solve } \\
\text { problems. }\end{array}$ & 1 & 2 & 3 & 4 & 5 & 6 & 7 & 8 & 9 \\
\hline 16 & $\begin{array}{l}\text { Everyone asked me to explain the } \\
\text { solution to the problem. }\end{array}$ & 1 & 2 & 3 & 4 & 5 & 6 & 7 & 8 & 9 \\
\hline 17 & I follow the lesson plan to learn & 1 & 2 & 3 & 4 & 5 & 6 & 7 & 8 & 9 \\
\hline 18 & $\begin{array}{l}\text { I understand the learning objectives of } \\
\text { this course. }\end{array}$ & 1 & 2 & 3 & 4 & 5 & 6 & 7 & 8 & 9 \\
\hline 19 & $\begin{array}{l}\text { I understand the goal I have to work on } \\
\text { in this course. }\end{array}$ & 1 & 2 & 3 & 4 & 5 & 6 & 7 & 8 & 9 \\
\hline 20 & I always concentrate on my class. & 1 & 2 & 3 & 4 & 5 & 6 & 7 & 8 & 9 \\
\hline 21 & $\begin{array}{l}\text { I try my best to understand the teaching } \\
\text { content. }\end{array}$ & 1 & 2 & 3 & 4 & 5 & 6 & 7 & 8 & 9 \\
\hline 22 & $\begin{array}{l}\text { The lecturer gave me as much attention } \\
\text { as other students. }\end{array}$ & 1 & 2 & 3 & 4 & 5 & 6 & 7 & 8 & 9 \\
\hline 23 & $\begin{array}{l}\text { The lecturer gave me as much help as } \\
\text { other students. }\end{array}$ & 1 & 2 & 3 & 4 & 5 & 6 & 7 & 8 & 9 \\
\hline 24 & $\begin{array}{l}\text { I have the opportunity to speak in class } \\
\text { as much as other students. }\end{array}$ & 1 & 2 & 3 & 4 & 5 & 6 & 7 & 8 & 9 \\
\hline 25 & $\begin{array}{l}\text { The lecture treats me as good as other } \\
\text { students. }\end{array}$ & 1 & 2 & 3 & 4 & 5 & 6 & 7 & 8 & 9 \\
\hline 26 & $\begin{array}{l}\text { I got the opportunity to participate in } \\
\text { the discussion in class, as much as } \\
\text { other students. }\end{array}$ & 1 & 2 & 3 & 4 & 5 & 6 & 7 & 8 & 9 \\
\hline
\end{tabular}

\section{Self-efficacy}

\begin{tabular}{|l|l|l|l|l|l|l|l|l|l|l|}
\hline \multicolumn{2}{|c|}{ Item } & \multicolumn{7}{|c|}{$\begin{array}{l}\text { 1=not agree at all } \\
9=\text { highest agreement }\end{array}$} \\
\hline 1 & $\begin{array}{l}\text { I believe I will receive an excellent grade } \\
\text { in this class. }\end{array}$ & 1 & 2 & 3 & 4 & 5 & 6 & 7 & 8 & 9 \\
\hline 2 & $\begin{array}{l}\text { I'm certain I can understand the most } \\
\text { difficult material presented in the } \\
\text { readings for this course }\end{array}$ & 1 & 2 & 3 & 4 & 5 & 6 & 7 & 8 & 9 \\
\hline 3 & $\begin{array}{l}\text { I'm confident I can learn the basic } \\
\text { concepts taught in this course. }\end{array}$ & 1 & 2 & 3 & 4 & 5 & 6 & 7 & 8 & 9 \\
\hline 4 & $\begin{array}{l}\text { I'm confident I can understand the most } \\
\text { complex material presented by the } \\
\text { instructor in this course. }\end{array}$ & 1 & 2 & 3 & 4 & 5 & 6 & 7 & 8 & 9 \\
\hline 5 & $\begin{array}{l}\text { I'm confident I can do an excellent job on } \\
\text { the assignments and tests in this } \\
\text { course. }\end{array}$ & 1 & 2 & 3 & 4 & 5 & 6 & 7 & 8 & 9 \\
\hline
\end{tabular}




\begin{tabular}{|l|l|l|l|l|l|l|l|l|l|l|}
6 & I expect to do well in this class & 1 & 2 & 3 & 4 & 5 & 6 & 7 & 8 & 9 \\
\hline 7 & $\begin{array}{l}\text { I'm certain I can master the skills being } \\
\text { taught in this class. }\end{array}$ & 1 & 2 & 3 & 4 & 5 & 6 & 7 & 8 & 9 \\
\hline 8 & $\begin{array}{l}\text { Considering the difficulty of this course, } \\
\text { the teacher, and my skills, I think I will } \\
\text { do well in }\end{array}$ & 1 & 2 & 3 & 4 & 5 & 6 & 7 & 8 & 9 \\
\hline
\end{tabular}

\section{Academic motivation}

\begin{tabular}{|c|c|c|c|c|c|c|c|c|c|c|}
\hline & Item & & ot & & & 10 & & & & \\
\hline 1 & $\begin{array}{l}\text { In a class like this, I prefer course } \\
\text { material that really challenges me so I } \\
\text { can learn new things. }\end{array}$ & 1 & 2 & 3 & 4 & 5 & 6 & 7 & 8 & 9 \\
\hline 2 & $\begin{array}{l}\text { In a class like this, I prefer course } \\
\text { material that arouses my curiosity, even } \\
\text { if it is difficult to learn. }\end{array}$ & 1 & 2 & 3 & 4 & 5 & 6 & 7 & 8 & 9 \\
\hline 3 & $\begin{array}{l}\text { The most satisfying thing for me in this } \\
\text { course is trying to understand the } \\
\text { content as thoroughly as possible }\end{array}$ & 1 & 2 & 3 & 4 & 5 & 6 & 7 & 8 & 9 \\
\hline 4 & $\begin{array}{l}\text { When I have the opportunity in this } \\
\text { class, I choose course assignments that } \\
\text { I can learn from even if they don't } \\
\text { guarantee a good grade }\end{array}$ & 1 & 2 & 3 & 4 & 5 & 6 & 7 & 8 & 9 \\
\hline 5 & $\begin{array}{l}\text { Getting a good grade in this class is the } \\
\text { most satisfying thing for me right now. }\end{array}$ & 1 & 2 & 3 & 4 & 5 & 6 & 7 & 8 & 9 \\
\hline 6 & $\begin{array}{l}\text { The most important thing for me right } \\
\text { now is improving my overall grade point } \\
\text { average, so my main concern in this } \\
\text { class is getting a good grade. }\end{array}$ & 1 & 2 & 3 & 4 & 5 & 6 & 7 & 8 & 9 \\
\hline 7 & $\begin{array}{l}\text { If I can, I want to get better grades in this } \\
\text { class than most of the other students }\end{array}$ & 1 & 2 & 3 & 4 & 5 & 6 & 7 & 8 & 9 \\
\hline 8 & $\begin{array}{l}\text { I want to do well in this class because it } \\
\text { is important to show my ability to my } \\
\text { family, friends, employer, or others }\end{array}$ & 1 & 2 & 3 & 4 & 5 & 6 & 7 & 8 & 9 \\
\hline
\end{tabular}

